\title{
Den borgerlige personregistrering i Sønderjylland
}

\author{
af Hans H. Worsøe
}

Ved Genforeningen i 1920 var det tanken, at »de sønderjyske Landsdele« på alle måder skulle ligestilles med resten af Danmark. Så langt er vi dog ikke nået. 75 år efter er der endnu forskelle i registreringen af fødsler, navngivelser og dødsfald nord og syd for Kongeåen. Landsarkivar Hans H. Worsøe, Aabenraa, belyser her, hvordan store dele af den borgerlige personregistrering fra preussisk tid blev bibeholdt i Sønderjylland efter 1920. I dag nærmer vi os måske det tidspunkt, hvor denne særlige ordning i Sønderjylland kan være forbillede for en modernisering af personregistreringen $i$ hele det nuværende Danmark.

Endnu i 75-året for Genforeningen findes der i Sønderjylland en række levn af den særlige lovgivning, der tidligere var gældende her, og som oftest var af tysk oprindelse. Noget af det, der mærkes mest af den enkelte borger, er forskellen på registreringen af fødsler, navngivelser og dødsfald. I Sønderjylland sker det hos personregisterføreren på rådhuset, i det øvrige Danmark hos sognepræsten eller på kordegnekontoret. Denne forskel bevirker, at man som født i Sønderjylland skal fremvise en fødselsattest f.eks. ved udstedelse af kørekort, mens man i det øvrige Danmark skal komme med en dåbsattest. Dette giver ofte anledning til undren og undertiden til misforståelser, da ikke alle myndigheder i det øvrige Danmark husker på denne forskel i påkommende tilfælde.

Spørgsmålet om, hvorfor denne forskel eksisterer, er med jævne mellemrum dukket op i pressen. I 1993 havde Jydske-Vestkysten således en stort opsat artikel med titlen »Bismarck spærrer for Kim - Forældre i Vojens overvejer at klage til Justitsministeriet«. Pointen i historien var, at i navngivningssager i Sønderjylland har Justitsministeriet det sidste ord, fordi den borgerlige personregistrering sorterer under dette ministerium, medens det i det øvrige land er Kirkeministeriet, der tager stilling til godkendelse af fornavne, og medens Kirkeministeriet har godkendt Kim som pigenavn, sagde Justitsministeriet altså nej. Da den borgerlige registrering oprindelig blev indført under det preussiske styre, var det klart, at det var Bismarcks skyld, at den lille pige ikke måtte hedde Kim.

I Folketinget rejste den socialdemokratiske politiker Svend Taanquist nogenlunde samtidig følgende spørgsmål over for justitsminister Hans Engell: »Skal den sønderjyske brug af både fødsels- og dåbsattest opretholdes, når der nu er gået mere end 70 år siden Genforeningen?« Da Erik Jacobsen fra Tinglev i 1994 
blev indvalgt i Folketinget for partiet Venstre, gjorde han det til sit bannermærke at få de sønderjyske særregler afskaffet. Partiet Venstre udsendte 25. okt. 1994 en pressemeddelelse, og her hed det under overskriften: »Fuld harmonisering mellem Sønderjylland og Danmark «: »På trods af, at det er godt 70 år siden, Sønderjylland blev genforenet med Danmark, eksisterer der stadigvæk særlove for den sønderjyske landsdel. Det kan unægtelig forekomme upraktisk. Jeg har derfor bedt regeringen tage initiativ til at nedsætte et udvalg, der skal udarbejde en betænkning om ophævelsen af særregler for Sønderjylland, således at der sker en fuldstændig regelharmonisering mellem landsdelene, lovgivningsmæssigt, og hvad angår administrative anordninger og evt. retssædvaner. Et konkret eksempel på Sønderjyllands særlovgivning er personregistreringen ...«

Dette udspil fra Erik Jacobsen gav anledning til megen debat i medierne, og statsministeren lovede at drøfte sagen med justitsministeren. I regeringen forberedtes samtidig et udspil om moderne informationsteknologi på grundlag af rapporten fra det såkaldte Dybkjær-udvalg. Udvalget stillede i udsigt, at informationsteknologien ville gøre det muligt at afskaffe de fleste af de hidtidige attester og det bureaukrati, der fulgte med. Og selvom der på forhånd er ytret megen skepsis overfor det »Borgerkort«, som udvalget foreslog, synes der omsider at være skabt en teknisk og - måske - politisk situation, hvor den bestående forskel i registreringen af fødsler, navngivelser og dødsfald vil kunne afskaffes. Det vil derfor være et naturligt tidspunkt nu at se tilbage på den borgerlige personregistrerings historie og give en fremstilling af dens udvikling med særlig henblik på forholdene i Sønderjylland.

\section{Den internationale baggrund}

Baggrunden for indførelse af en borgerlig registrering af fødsler, vielser og dødsfald skal søges i magtkampen mellem kirke og stat med hensyn til retten til at stifte retsgyldige ægteskaber. Efter reformationen blev problemet om, hvilke myndigheder, der havde denne ret, for alvor aktuelt i de stater, hvor der fandtes flere konkurrerende kirkesamfund. Allerede i 1580 skabtes der i provinserne Holland og Vestfriesland mulighed for borgerligt ægteskab som et alternativ, og i 1658 blev borgerlig vielse obligatorisk i England. Den fulde konsekvens blev imidlertid først taget i Frankrig efter revolutionen. I den franske forfatning fra $1791 \mathrm{blev}$ ægteskabet erklæret for en »contrat sociak. Dette blev fulgt op med »Loi qui détermine le mode de constater l'état civil des citoyens«, d.v.s. loven som fastlægger reglerne for dokumentationen af borgernes civilstandsforhold, dateret 20. sept. 1792. Med denne lov indførtes tvungen borgerlig vielse og statslig registrering af fødsler og dødsfald. De særlige regi- 
stre skulle føres på borgmesterkontorerne (»le mairie«) enten af borgmesteren eller af en af ham bemyndiget person. Med den franske indlemmelse af områderne på den venstre Rhin-bred indførtes sådanne registre også i disse områder, hvor de betegnedes »Mairieregister« eller "Zivilstandsregister«, jvf. loven af 28. Pluviôse år VIII (dvs. 17. febr. 1800). Ordningen strakte sig herudover bl.a. til byerne Bremen og Hamborg og forblev mange steder i kraft efter det franske kejserriges sammenbrud.

\section{Forholdene i Preussen og Det tyske Rige}

I 1794 indførtes i Preussen den såkaldte Preussische Landrecht, hvis indhold var tydeligt påvirket af Naturretten. Landretten indeholdt en fælles ægteskabslovgivning for alle konfessioner uden dog at drage de fulde konsekvenser. Således forblev en kirkevielse, hvor en sådan blev foretaget, den retsstiftende, og den borgerlige vielse var kun at betragte som et alternativ. Der indførtes derfor heller ikke generel borgerlig civilstandsregistrering.

I 1848 førte kravet om en adskillelse af stat og kirke til en principvedtagelse af, at borgerlig vielse skal gå forud for kirkelig, og et løfte om indførelse af borgerligt ægteskab og civilstandsregistre indgår i det preussiske forfatningsdokument af 31.jan. 1850. Det kom imidlertid ikke foreløbig længere end til denne teoretiske beslutning, og et forslag om borgerlig vielse blev forkastet af den preussiske landdags førstekammer Herrenhaus i 1860.

Efter udstedelse af det pavelige ufejlbarlighedsdogme i 1870 tilspidsedes modsætningsforholdet mellem de katolske centrumspolitikere og den preussiske regering, men også på rigstysk basis ønskede man forholdet mellem stat og kirke afklaret. Ved rigsdagssamlingen 1872 blev der stillet dagsordensforslag med opfordring til rigskansleren om at arbejde på at få gennemført obligatorisk borgerlig vielse og en nyordning af civilstandsregistreringen. Vanskeligheder med bl.a. at tage hensyn til de mange forskellige eksisterende ordninger $i$ enkeltstaterne forsinkede imidlertid afslutningen af sagen, og den 10. dec. 1873 fremsatte den preussiske kultusminister et lovforslag for Preussens vedkommende, som indebar tvungen borgerlig vielse og indførelse af borgerlig registrering af fødsler og dødsfald. Forslaget blev vedtaget, og »Gesetz über die Beurkundung des Personenstandes und die Form der Eheschliessung « af 9. marts 1874 kunne derefter træde i kraft indenfor det preussiske landområde med virkning fra 1 .oktober 1874 .

I den følgende tid blev spørgsmålet igen drøftet $\mathrm{i}$ den tyske rigsdag, hvor man udfra ønsket om en ensartethed i lovgivningen i de forskellige lande kom til enighed om at lade bestemmelserne galde i samtlige lande uanset hvilke 
regler, der hidtil havde været gældende. "Gesetz über die Beurkundung des Personenstandes und die Eheschliessung für das deutsche Reich «, som er dateret 6. febr. 1875, kom til at ligge meget tæt op ad den preussiske lov, men tidspunktet for dens ikrafttræden blev overladt til de enkelte lande, dog skulle det ske senest pr. 1.januar 1876. I Preussen valgte man at lade lovens 3. afsnit, der indeholder reglerne om ægteskabs indgåelse, træde i kraft 1.marts 1875, den øvrige del 1.jan. 1876. For førelsen af civilstandsregistrene betød rigsloven ikke større ændringer, men regeringen i Slesvig benyttede lejligheden til i november 1875 at udsende fortryk af de nye, let reviderede skemaer, og 16. dec. 1875 udsendtes et cirkulære med gennemgang af de vigtigste bestemmelser og en almindelig understregning af, at det var vigtigt, at reglerne blev overholdt.

\section{Etableringen af civilstandsregistre $i$ Sønderjylland}

I løbet af månederne august og september 1874 udsendte overpræsident von Scheel-Plessen for hver kreds et cirkulære, der fastlagde de enkelte distrikter (Standesamtbezirke) og udpegede de ansvarlige embedsmænd (Standesbeamte) og deres stedfortrædere. Som personregisterførere udpegedes i overvejende grad kommuneforstanderne, men først med rigsloven fra 1875 blev disse selvskrevne. Ved udsendelsen af cirkulæret for Haderslev amt 21. aug. 1874 var det endnu ikke lykkedes at finde egnede personer i Fjelstrup, Stepping, Vojens, Sommersted og Nustrup. De blev så separat udnævnt en måned senere, således at alle kunne påbegynde deres virksomhed pr. 1.okt. 1874, således som loven krævede det.

Medens de tyske betegnelser var fastsat i loven, var man i tvivl om, hvilke danske betegnelser, der skulle anvendes for de nye funktioner og den nye embedsmand $\mathrm{i}$ de tosprogede vejledninger, de enkelte landråder lod offentliggøre i det lokale Kreisblatt. I Tønder og Aabenraa amter anvendte man udtrykkene bestillingsmandskredse/amter og bestillingsmænd, medens deres domicil blev betegnet bestillingsmandssædet. I Haderslev hed det civilstandamtsdistrikter og civilstandsembedsmænd, i Sønderborg standesamtdistrikt og standesembedsmænd, men også her gik man efterhånden også over til at benytte civilstandsembedsmænd. Da embedssproget var tysk, og de fortrykte skemaer samt senere forordninger kun kom på tysk, synes der ikke at foreligge nogen fælles dansk betegnelse før langt senere. Til illustration af vanskelighederne ved at udtrykke sig på dansk skal paragraf 2 af Tønderlandrådens bekendtgørelse af 15. sept. 1874 citeres. Den lyder:

»Hvad angaaer Localiteterne for Bestillingsmandsamterne, saa er det selvforstaaelig, at ikke overalt kan forlanges at have Lokaler, som udelukkede afbenyttes til at optage Bestillingsacterne. Dog maa overalt forlanges, at den hertil afbenyttede Localitet svarer til Actens Værdighed, at Lokalet altsaa 
navnlig er et saadant, fra hvilket uvedkommede Personer til enhver Tid kunne bortfjernes.

Amtslokalet er i stedbrugelig Maade (ved et Skilt) at kjendeliggjøre. Med Hensyn til et desangaaende Tilbud fra A. Liebman's Graveer- og Præg-Anstalt i Berlin, som er beredt til at anfærdige Skilte med Ørn for en billig Priis, vil en Bekjendtgjørelse udkomme i Amtsbladet «.

Ved inddelingen i distrikter fulgtes hovedsagelig sognegrænserne, og der blev kun undtagelsesvis taget hensyn til opdelingen i de mange små preussiske kommuner. Antallet af distrikter i de enkelte kredse var følgende: Haderslev 25, Aabenraa, Sønderborg og Tønder (nord for den nuværende grænse) hver 18, hvortil kom Bov fra Flensborg amt, således at den del af Sønderjylland, der i 1920 kom til Danmark, omfattede ialt 80 distrikter.

\section{Lovens indhold}

Selve loven er inddelt i 8 afsnit, hvoraf det første indeholder de almindelige bestemmelser om distriktsinddeling, udnævnelse af personregisterførere og stedfortrædere, tilsynsmyndighed (for byerne: regeringen, for landdistrikterne: landråden) samt de overordnede regler for førelsen af fødsels-, vielses- og dødsregistrene i to eksemplarer. Af disse indleveres genparten (Nebenregister) ved hvert års slutning til kontrolmyndigheden, der efter godkendelse sender det til opbevaring ved den stedlige underret (fra 1889: amtsretten). Endelig fastslåes det $i$ forste afsnit, at registrenes oplysninger har beviskraft i retssager.

Andet afsnit handler om fødsler, hvori det bestemmes, at alle fødsler skal anmeldes indenfor en uge. Anmeldelsespligtige er, i rækkefølge: ægtemanden, jordemoderen, en evt. tilstedeværende læge, andre tilstedeværende eller moderen, så snart hun er i stand til det. Anmeldelsen er mundtlig, men i 1875

Titelfelt fra landsarkivets hovedeksemplar af det forste fodselsregister fra Abild. Hovedregistrene afleveres til landsarkivet 100 år efter at de er udskrevne. Derfor skal landsarkivet udstede alle fodselsattester fra tiden op til 1895.

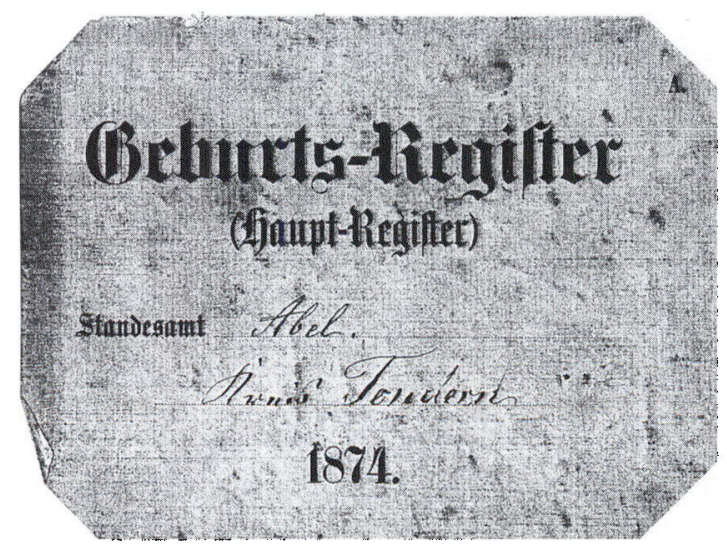


indskærpes det, at personregisterføreren har pligt til at forvisse sig om, at oplysningerne er rigtige. Hvis barnets fornavn ikke er bestemt ved fødslen, skal det anmeldes inden to måneder.

Tredie og fjerde afsnit handler om vielse. Først om de betingelser, der skal opfyldes, og som personregisterføreren er prøvelsesmyndighed for, hvorefter det fastslåes, at fremover er kun ægteskaber, der er indgået hos en personregisterfører gyldige i Det tyske Rige. I femte afsnit bestemmes, at alle dødsfald skal anmeldes senest første hverdag efter, at de er indtrådt, samt at begravelser ikke må foretages uden attest fra personregisterføreren. Anmeldelsespligtig er familieoverhovedet, ellẹ hvis et sådant ikke findes, husværten. Sjette afsnit bestemmer, at fødsler og dødsfald til søs skal indføres i skipperens logbog, og at skipperen i første havn, hvor det er muligt, skal aflevere en afskrift til personregisterføreren, der derefter lader den gå videre til rette personregister. I syvende afsnit bestemmes, at rettelser kun kan foretages efter retskendelse, en bestemmelse, der senere viste sig at være så upraktisk, at reglerne blev lempet. Endelig indeholder ottende afsnit straffebestemmelserne ved overtrædelse af reglerne samt en vejledning om forholdet til de kirkelige myndigheder. Det er i den forbindelse værd at bemærke, at følgecirkulæret fra regeringen i Slesvig, dateret 16. dec. 1875, i sin slutning fremhæver, at de kirkelige forpligtelser med hensyn til dåb og vielse ikke berøres af loven, $\mathrm{g}$ at man derfor må forvente af personregisterførerne, at de ved udførelsen af deres embedspligter $i$ videst muligt omfang medvirker til, at parterne ikke forsømmer deres kirkelige forpligtelser. Den hidtidige kirkelige registrering fortsætter således sideløbende, men nu blot uden retsgyldighed. For navngivningens vedkommende f.eks. vil det sige, at er der uoverensstemmelse mellem kirkebog og personregister $\mathrm{i}$ henseende til navnets stavemåde, er det formen i personregisterets hovedeksemplar, der er gyldig. Og således er det endnu i 1995.

Det er værd at bemærke, at medens personregisterføreren med hensyn til fødsler, navngivelser og dødsfald udelukkende er registreringsmyndighed, var han efter lovene af 1874 og 1875 ved vielser også - eller måske rettere: først og fremmest - prøvelses- og vielsesmyndighed. Forskellen består i, at ved fødsler, navngivelser og dødsfald registrerer han blot handlinger, der er foregået, medens han ved vielser først skal godkende, at vielsen må foretages, hvorefter han selv udfører den retsstiftende handling. Dette faktum er ofte overset, men er en naturlig konsekvens af den borgerlige registrerings forhistorie.

\section{Skemaernes indhold}

Skemaernes indhold og udformning forblev stort set uændret i perioden frem til Genforeningen, og da de indeholdte oplysninger som nævnt ovenfor har retlig beviskraft er det vigtigt at vide, hvad man kan finde oplyst her. 
Skemaet for anmeldelse af fødsler skal i udfyldt stand indeholde følgende oplysninger: anmelderens fulde navn, stilling og bopæl. Barnets fødselstidspunkt (dag og klokkeslet) og fødested, dets køn og fornavne samt forældrenes fulde navne, religion, stilling og bopæl. Ved fødsler uden for ægteskab anføres faderen kun, hvis han personligt overfor personregisterføreren har vedkendt sig barnet, eller der forelå en retlig bekræftelse på faderskabet. Dødfødte anføres kun i dødsregisteret.

I vielsesregisteret, der omfatter to sider for hver vielse, oplyses brudefolkenes fulde navne, alder, religion, fødested og bopæl samt deres forældres fulde navne, stilling og bopæl. Også forlovernes fulde navn og bopæl oplyses. Skemaets tekst oplyste oprindelig kun, at parterne i vidners nærværelse personlig havde erklæret, at de ville indgå ægteskab, men ikke at de faktisk var blevet viet. Dette blev rettet i 1876 , hvor teksten blev udvidet med ordlyden af personregisterførerens spørgsmål til de forlovede og deres svar, hvorefter han erklærede dem for rette ægtefolk at være. De foreskrevne regler om, at senere skilsmisser skulle noteres i ægteskabsregisteret, synes ikke at være blevet fulgt.

Dødsregistrene anfører anmelderens fulde navn, stilling og bopæl, dag, time og sted for dødens indtræden, den afdødes fulde navn, religion, alder, stilling, bopæl og fødested, ægtefællens fulde navn eller, at afdøde var ugift, afdødes forældres fulde navne, stilling og sidste bopæl. Især den sidste oplysning kan ofte være vigtig ved personalhistoriske eftersøgninger.

\section{Personregistrene 1874-1920}

Desværre har de færreste personregisterførere sørget for, at deres embedsarkiv er overleveret til efterverdenen, bortset naturligvis fra selve personregistrene. De få bevarede arkiver sætter os dog nogenlunde i stand til at følge forvaltningen på dette specielle område gennem hele det preussiske embedssystem helt ned til lokalforvaltningen. Der må her ligge et oplagt emne for en specialeafhandling for en historiestuderende. Her skal blot gives nogle få eksempler fra et par af disse arkiver.

Den 7. sept. 1874 blev gårdmand Hans Christian Jensens udnævnelse til personregisterfører i Abild underskrevet af overpresident Scheel-Plessen. Dette blev ham 16. sept. meddelt af landråden i Tønder, der samtidig indkaldte ham til edsaflæggelse som preussisk embedsmand inden for 14 dage. Han var en af de få personregisterførere i området, der ikke samtidig var kommuneforstander. Som stedfortræder (eller som det hed i landrådens skrivelse »istedtræder «) udnævntes degn og førstelærer Peter Petersen i Abild. Sammen med udnævnelsen fulgte en af overpræsidenten udarbejdet instruks på fire sider, en stak formularer og skemaer samt besked om hvert kvartal at indberette dødsfald i distriktet til Erbschaftssteueramt i Altona. Desuden skulle alle dødsfald og 
fødsler, som kunne tænkes at ville føre til sager om formynderskab straks indberettes til underretten. Dette var kun begyndelsen til indberetningspligten, hvorved personregisterførerne blev et vigtigt led i det samlede statsapparat. Den videre udvikling af denne samt de mange mindre ændringer af administrativ karakter skal ikke her følges, men der skal dog gøres opmærksom på, at indførelsen af den borgerlige retsbog (Bürgerliches Gesetzbuch, forkortet BGB) pr. 1.jan. 1900 medførte flere ændringer for personregisterførerne. Der blev derfor udsendt en ny samlet instruks underskrevet af rigskansleren og dateret 25. marts 1899. En gennemgang af de bevarede personregisterføreres arkiver vil kunne fremdrage mange flere enkeltheder af administrativ og historisk interesse.

Til slut skal det nævnes, at Indenrigsministeriet i Berlin 9. sept. 1914 udsendte forskrifter om, at dødsfald blandt militærpersoner af vedkommende troppeenhed, f.eks. regimentschefen, skal indberettes til personregisterføreren i den kommune, hvor den afdøde havde hjemsted ved indkaldelsen. Dette betyder i praksis, at faldne sonderjyske krigsdeltageres data, herunder oplysninger om dødssted, kan findes $\mathrm{i}$ de pågældendes hjemstedskommuners personregistre, såfremt de er meldt faldet $\mathrm{og}$ ikke blot savnet. Anmeldelsen kan undertiden være år forsinket, men er en god og ofte overset kilde til oplysning om disse soldaters skæbne.

Ved verdenskrigens afslutning havde den borgerlige personregistrering fungeret i Sønderjylland i 44 år og var således ganske godt indarbejdet. Spørgsmålet var derfor, om man uden videre skulle indføre de i Danmark gældende regler på området efter Genforeningen, eller om man her havde et af de tilfælde, hvor dansk lovgivning var mindre tidssvarende og i stedet burde tillempes efter de i Sønderjylland galdende regler?

\section{Forholdene i Danmark}

I Danmark foregik civilstandsregistreringen ved ministerialbogsførerne, dvs. i kirkebøgerne, men tanken om en ikke-kirkelig registrering var heller ikke ukendt her. Med hensyn til vielser var der ved lov af 13.april 1851 indført en såkaldt nødcivilægteskabsordning, hvorefter der kunne gives tilladelse til borgerligt ægteskab for fritænkere og folk med forskellig konfession (blandede ægteskaber). I 1859 fremlagde historikeren Frederik Barfod i Folketinget et gennemarbejdet forslag om borgerlige civilstandsregistre (sognebøger) og tvungen borgerlig vielse, men forslaget blev ikke vedtaget. Derimod fik Venstre rent faktisk efter systemskiftet 1901 i Folketinget vedtaget et forslag om tvungen borgerlig vielse, men dette blev standset i Landstinget. Spørgsmålet blev indgå- 


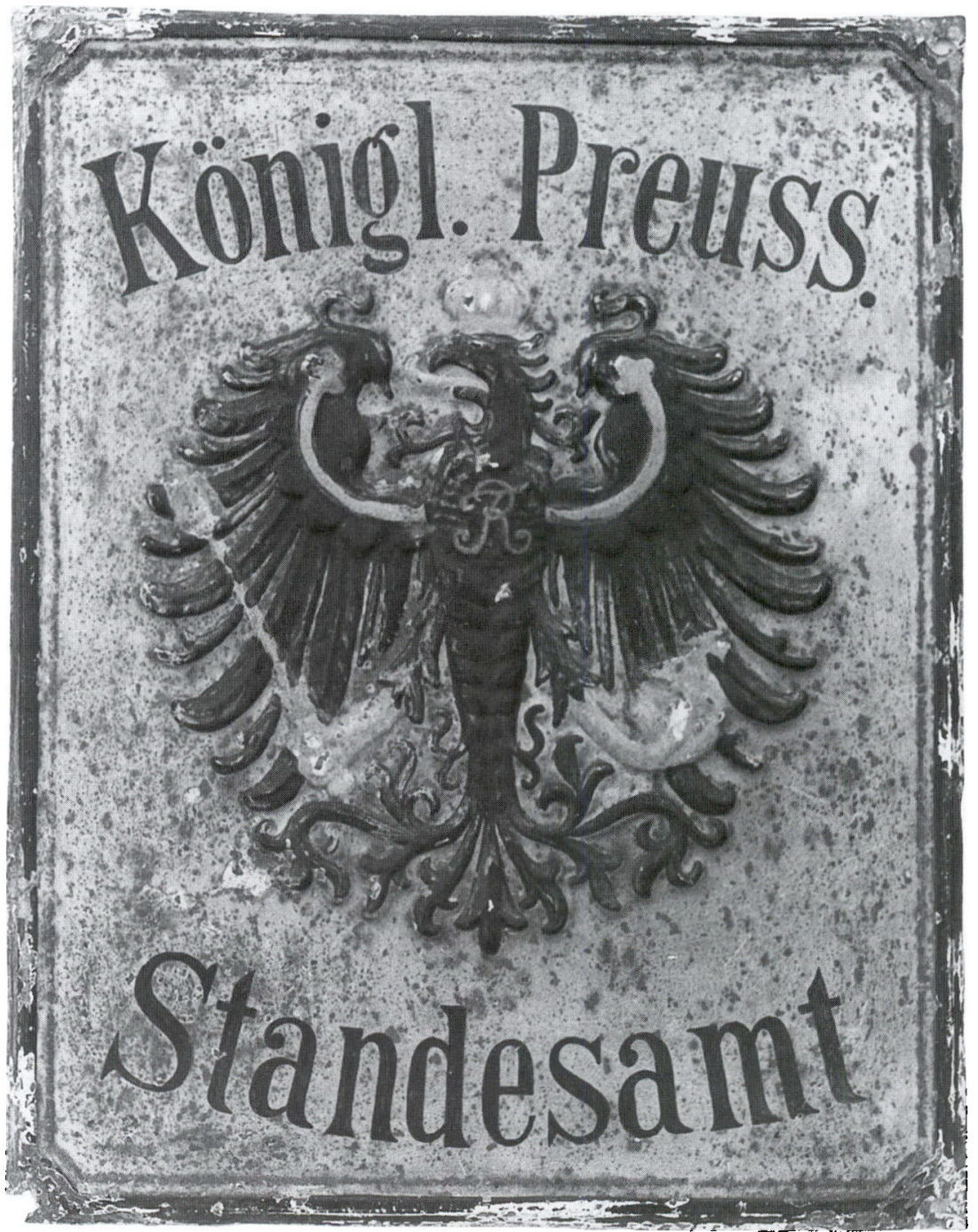

Op til Genforeningen kunne man over hele Sonderjylland se skilte som dette. Det markerede, at her havde "der Standesheamte" sit kontor. Dette Standesamt-skilt kan med monogrammet FR dateres til 1888, det såkaldte "Dreikaiserjahr". Wilhelm I dode i marts, og efterfolgeren, den dodssyge Friedrich III, fik kun tre màneder på tronen, indtil han blev efierfulgt af Wilhelm II. Landsarkivet. Foto: Sven Geerthsen.

ende behandlet i Det kirkelige Udvalg i perioden 1904-07, hvor både tvunget borgerligt ægteskab og civilstandsregistre blev drøftet, men heller ikke ved den lejlighed førte det til noget resultat. Også i Danmark indgik kampen om det 
borgerlige ægteskab således i striden mellem Højre og Venstre, men i modsætning til Tyskland var det ikke lykkedes at få en nyordning gennemført.

\section{Loven af 28. juni 1920}

Blandt de mange love, der i 1920 skulle behandles først i rigsdagspartiernes sønderjyske udvalg og derefter i Rigsdagens to kamre var »Loven om Indførelse af dansk Personret, Familieret og Arveret i de sønderjyske Landsdele«. I lovens paragraf 4 slåes fast, at bestemmelserne om de borgerlige personregistre i Sønderjylland med hensyn til anmeldelse af fødsler, navngivelse og dødsfald forbliver i kraft med de ændringer, som måtte blive fastsat af justitsministeren, dog at amtsretternes hidtidige funktion overtages af underretterne. Paragrafferne 7-12 indeholder reglerne i forbindelse med indgåelse af ægteskab, hvor det i paragraf 9 bestemmes, at ægteskab kan indgåes for personregisterføreren, når mindst en af personerne har bopæl eller sædvanligt ophold i de sønderjyske landsdele.

Baggrunden for bibeholdelsen af personregistrene fremgår tydeligt, når man følger lovforslagets tilblivelse. Som ved de andre sønderjyske love var det professor dr. jur. Vinding Kruse, det sønderjyske ministeriums juridiske konsulent dr.jur. N.Cohn, kontorchef i Justitsministeriet Aage Svendsen og sagfører, senere borgmester i Haderslev A. Thulstrup, der udgjorde den juridiske ekspertise. Ved forelæggelsen 28. april 1920 i det sønderjyske udvalg anførtes indledningsvis, at det ikke kunne lade sig gøre uden varsel at erstatte bestemmelserne i Bürgerliches Gesetzbuch med dansk ret på alle områder. Det var nødvendigt med en overgangstid, som blev foreslået gående til september 1921. I udvalget drøftedes mulighederne for at forlænge fristen for bestemmelserne om ægteskabs indgåelse for at afvente vedtagelsen af de nye danske love, som var under forberedelse. Da borgerligt ægteskab i Danmark, som ovenfor anført, kun var muligt, hvis mindst den ene part ikke var medlem af folkekirken, ønskede man reglerne således formuleret, at Sønderjylland ikke blev et fristed for folk, der nok var medlemmer af folkekirken, men ikke kunne eller ville vies kirkeligt. Med hensyn til de øvrige forhold omkring personregistrene var holdningen derimod ganske klar, således som den fremgår af bemærkningerne ved lovforslagets fremlæggelse i udvalget. Det hed her:

»I de sønderjyske Landsdele føres der borgerlige Registre over Fødsler, Ægteskaber og Dødsfald af særlige Embedsmænd (Standesbeamter). At faa saadanne Registre indført i det øvrige Danmark ville være i høj Grad ønskeligt; der er derfor al Grund til at bevare disse Registre og Pligten til at foretage Anmeldelser til dem. Naar dette sker, er der ingen Grund til at paalægge Borgerne nogen Pligt til at foretage Anmeldelser til Kirkebøgerne, hvor ingen kirkelig Handling skal foretages. En saadan Pligt bestaar ikke for Tiden, hvor- 
imod Præsterne periodisk plejer at faa Afskrifter af Anmeldelserne til det borgerlige Register vedrørende Medlemmer af Folkekirken, for at de kan kontrollere, om Daab og kirkelig Vielse foretages ...

Ogsaa de nærmere regler om Personregistrene tænkes opretholdt i det væsentlige uforandret, kun at Sproget normalt bliver Dansk; af Hensyn til den Mulighed, at ogsaa enkelte andre Bestemmelser skulde trænge til Fndring, har man givet Justitsministeren en almindelig Beføjelse til at ændre Reglerne«.

I udvalget synes der ikke at have været bemærkninger til tanken om at bevare personregistrene, og da justitsminister Svenning Rytter 23. juni 1920 forelagde forslaget i Folketinget, var der ingen, der ønskede ordet, hvorfor det straks gik videre til anden behandling og vedtagelse uden afstemning. Ved behandlingen i Landstinget var talelysten større, men til det specielle punkt om personregistrene og disses forventede indførelse i Danmark, som klart fremgik af de trykte bemærkninger til lovforslaget, var der heller ikke her bemærkninger. Lovens praktiske udførelse lå nu i justitsministerens hånd.

\section{Loven folges op}

Da lovens ordlyd allerede inden vedtagelsen havde været forelagt de to danske landråder, senere amtmænd, Kr. Refslund Thomsen og grev O. D. Schack, kunne førstnævnte allerede 19.juni 1920 rejse det rent praktiske spørgsmål om tilvejebringelsen af danske blanketter til afløsning af de tyske, som hidtil var blevet rekvireret fra regeringen i Slesvig. Sagen blev af Justitsministeriet sendt til høring hos admininistrator for de sønderjyske Landsdele, som efter indhentet udtalelse fra de fire amter kunne indberette, at der i befolkningen var et stærkt ønske om så hurtigt som muligt at få danske skemaer og blanketter, og at man derfor kun i en så kort overgangstid som muligt burde fortsætte med de tyske. Som skæringsdag foreslog han 1.jan. 1921. Trykningen skulle ske på Justitsministeriets foranledning, hvorfra amterne kunne rekvirere dem til videre fordeling. Samtidig foreslog administrator, at amtmændene overtog regeringspræsidentens hidtidige bemyndigelse til udnævnelse af personregisterførerne.

Allerede 31.aug. 1920 kunne Justitsministeriet udsende Bekendtgørelse om Førelse af borgerlige Personregistre i de sønderjyske Landsdele, som var ledsaget af et tryk af de nye danske skemaer og blanketter. De nye blanketter m.v. skulle tages i brug 1.okt. 1920. De enkelte købstæder, flækker og landsogne kom hver til at udgøre et distrikt med borgmesteren/sognefogden som personregisterfører, idet dog amtmanden undtagelsesvis kunne beskikke en anden. I sogne med flere sognefogeddistrikter førtes der særskilte protokoller for hvert distrikt. Det overordnede tilsyn med registrene påhvilede amtmanden.

Med disse klare regler var de mange tvivlsspørgsmål, der havde skabt 


\section{Nr. 85}

Apamade , am Lt gumi 1918

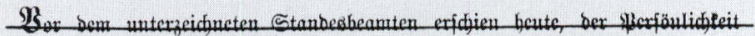

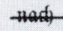

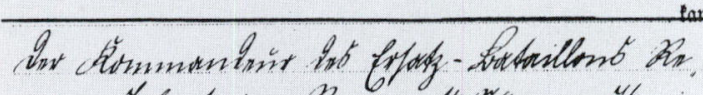

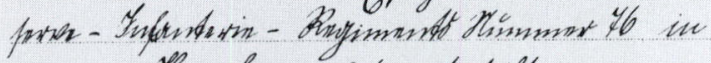
Deambury fot midgratsild,

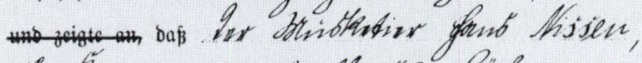

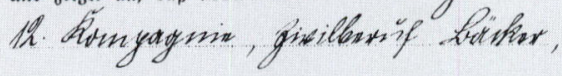

maingefn Yofon alt, nomyoliffor Retigion,

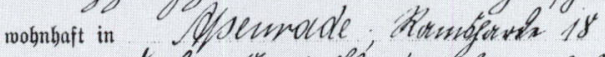

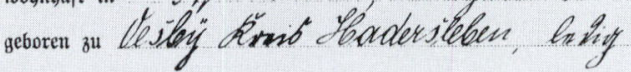

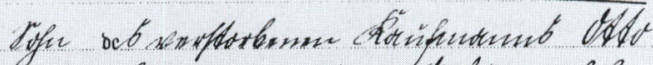

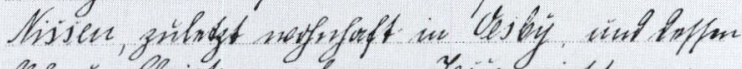

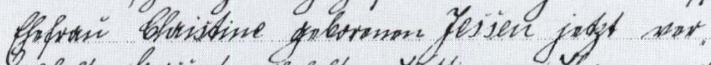

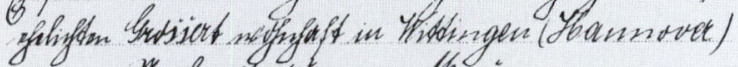

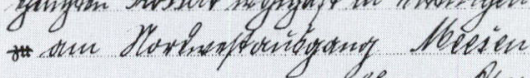
am

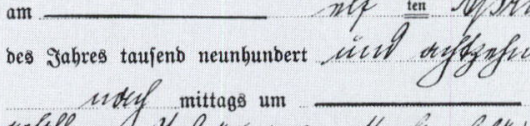

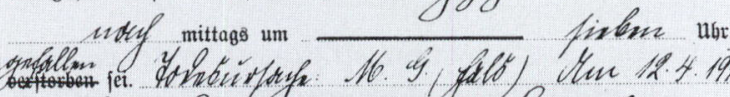

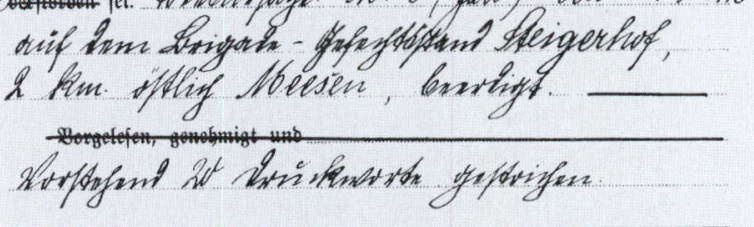

I dodsregistrene fra årene 1914-18 blev der foretaget registrering af dodsfald ved fronterne, her meddelelse fra kommandanten over erstatningsbatallionen $i$ reserveinfanteriregiment 76 om musketer Hans Nissens endeligt. Han var 19 år gammel og i det civile liv bager med bopal Ramsherred 18 i Aabenraa. Den 11. april 1918 faldt han ved Meesen og blev hegravet ved Steigerhof $2 \mathrm{~km}$ ost for Meesen. Dodsfaldet blev registreret i personregisteret $i$ Aabenraa, fordi Nissen boede dér for indkaldelsen. 
uklarhed i overgangstiden, ryddet af vejen: skulle de gamle distrikter opretholdes, kunne de hidtidige personregisterførere fortsætte, og lå tilsynsmyndigheden hos dommeren, politimesteren eller amtmanden? Med udnavnelsen af de nye sognefogder var personspørgsmålet også løst, og den praktiske overdragelse kunne finde sted. I Sønderborg amt skete dette ved en rundskrivelse til de daværende registerførere og fremsendelse af Justitsministeriets ovennævnte bekendtgørelse til de nye ledsaget af en skrivelse fra amtmanden dateret 20. sept. 1920. I de følgende måneder fulgte en lang række rundskrivelser og meddelelser fra amtmanden, hvori indberetningspligt og andre funktioner defineredes eller indskærpedes efter behov. Alt i alt må overgangen fra tyske til danske registre og personregisterførere siges at være foregået uden de store problemer.

\section{Borgerlig vielse}

Et særligt problem udgjorde vielserne. I Danmark havde den radikale regering i perioden op til Genforeningen forsøgt at indføre tvungen borgerlig vielse, men selvom forslaget blev støttet af grundtvigske kredse, kunne det ikke gennemføres. De nye danske præster i Sønderjylland fulgte i vid udstrækning de nord for Kongeåen galdende regler med det resultat, at der i perioden fra 15.juni 1920 blev foretaget en del kirkelige vielser i Sønderjylland uden forudgående indgåelse af ægteskabet for en personregisterfører. Da sådanne vielser reelt var uden borgerlig gyldighed, blev der 6. maj 1921 gennemført en særlig lov, som tillagde kirkelige vielser i tiden 15.juni 1920 til 15.apr. 1921 ægteskabsstiftende virkning. For at få orden i sagerne henstillede Justitsministeriet 7. maj til Kirkeministeriet, at de pålagde præsterne at indberette sådanne ægteskaber til personregisterførerne, hvorefter de blev optaget i personregistrene med henvisning til loven.

Ved Lov om Ægteskabs Indgåelse og Opløsning af 30.juni 1922 med ikrafttræden 1.jan. 1923 indførtes i hele Danmark valgfrihed mellem kirkelig og borgerlig vielse. Dette gjaldt også prøvelsen (lysningen) således at forstå, at adgang til borgerlig vielse nu var åben for alle, uanset om betingelserne for kirkelig vielse var til stede eller ikke. Borgerlig vielse forrettes af borgmesteren/ sognefogden og indføres i en særlig protokol, der føres i to eksemplarer. De nærmere regler herfor fulgte i en kgl. anordning af 17. nov. 1922. Hverken her eller i loven nævnes forholdet til personregisterførerne. For at undgå total forvirring var det nødvendigt for amtmændene at udsende særlige instrukser til disse, idet man skal huske, at den sognefoged, som nu skulle forrette den borgerlige vielse $i$ langt de fleste tilfælde var identisk med den personregisterfører, der fortsat skulle føre de hidtidige registre. For Sønderborg amts vedkommende skete dette ved skrivelse af 11.dec. 1922, hvor det bl.a. hed: 
"Ægteskabsregistrene og Biregistrene for Aaret 1923 indrettes i Overensstemmelse med Justitsministeriets Bekendtgørelse af 20. Nov. 1922 ... Saafremt Ægteskabsregistre for Aaret 1923 allerede maatte være anskaffet, udskydes Endringen af disse til Aaret 1924 ... I Sogne, hvor Personregisterføreren ikke er Sognefoged, kan Registerføreren i Fremtiden ikke foretage Vielse. Borgmesteren henhv. Sognefogden, som fører Ægteskabsbogen og Duplikatet, tilstiller Personregisterføreren Udskrift af Ægteskabsbogen. Personregisterføreren indfører denne Udskrift i Ægteskabsregisteret og Biregisteret ...«.

Situationen var således den, at personregisterføreren nu også for ægteskabsområdet var reduceret til registreringsmyndighed, således som han hele tiden havde været det for fødsler og dødsfald. Hermed var et af de oprindeligt stærkeste motiver til borgerlig registrering taget ud af sammenhængen, men dette synes ikke at have spillet nogen rolle ved vurderingen af de fremtidige forhold. For vielser i Sønderjylland var forholdet nu det, at kirkelige vielser registreredes i kirkebogen, borgerlige i de nye ægteskabsbøger og samtlige vielser stadig i personregistrene. Det sidste var en helt tom formalitet, hvilket klart fremgår af, at Statistisk Departement fra og med 1923 fritog personregisterførerne (men ikke sognefogderne) for indberetningspligt om ægteskaber. Denne ganske overflødige dobbeltregistrering blev først ophævet i 1926, jvf. nedenfor.

At det ikke altid var helt nemt at holde funktionerne som sognefoged og som personregisterfører adskilt, viser en lille episode om aflønningen. Som personregisterfører modtog man en betaling på 30 øre om året pr. indbygger. I sognefoged- og lægdsmandsforeningen havde man fået den opfattelse, at de 10 øre var for at føre de borgerlige ægteskabsbøger, og at det dèrfor var naturligt, at alle sognefogder fik denne betaling, altså også i det øvrige Danmark. Men nej; sagen endte i Justitsministeriet, som belærte den om, at de to ting ikke havde noget med hinanden at gøre, selv om der som regel var personsammenfald i Sønderjylland. Som et lille plaster på såret tilføjedes, at Indenrigsministeriet i øvrigt ville finde en godtgørelse til sognefogderne på 10 øre rimelig - ikke pr. indbygger pr. år, men for hver foretaget vielse, når sognefogden vel at mærke selv stillede et passende lokale til rådighed!

Bekendtgorelsen af 2.jan. 1926

Med loven om oprettelse af folkeregistre i Danmmark, der trådte i kraft 1.apr. 1924, tog Danmark endnu et lille skridt på vej til borgerlig registrering, men uden at drage konsekvenserne, idet loven blot fastslog, at de myndigheder, overfor hvilke fødsler, navngivelse og dødsfald skulle anmeldes, var pligtige til at afgive indberetning til de nye kommunale folkeregistre. Ved loven ophævedes de hidtidige sønderjyske melderegistre, hvori flytninger registreredes, men personregistrene berørtes ikke. 
Dette skete først to år senere, hvor den endelige fordanskning af lovgivningen blev gennemført ved Justitsministeriets bekendtgørelse af 2.jan. 1926 om „Førelse af de borgerlige Personregistre i de sønderjyske Landsdele«. Hermed var overgangsperioden slut efter at have varet $5 \frac{1}{2}$ år mod de stipulerede 2$2 \frac{1}{2}$ år, og hermed gled personregisterførerens registrering af vielser omsider ud.

I bestemmelserne fra 1920 var optaget en række henvisninger til tysk lovgivning, som stadig havde gyldighed. De vigtigste gjaldt forholdene omkring lysning og borgerlig vielse, og disse var naturligvis bortfaldet med de danske ægteskabslove i 1923. Derimod var der stadig en række straffebestemmelser fra rigsloven af 6 . febr. $1875 \mathrm{i}$ kraft, ligesom personregisterførerens bemyndigelse til at bevidne de til ham anmeldte handlinger hvilede på Bürgerliches Gesetzbuch. Endnu i april 1925 måtte amtmand Lundbye »henlede de Herr. Personregisterføreres opmærksomhed på Bestemmelsen i $\S 68$ "Personenstandgesetz«, hvorefter den, der ikke efterkommer den i $\$ 17$ til 20, 22 til 24 og 56 til 58 i forannævnte Lov foreskrevne Anmeldelsespligt, straffes med Bøder eller simpelt Fængsel«. Personregisterførerne anmodedes om i tilfælde af overtrædelse at anmelde vedkommende til politimesteren. Det var derfor naturligt, at der i slutbemærkningerne til 1926-bekendtgørelsen udtrykkelig gøres opmærksom på, at tysk rigslov om personstandsregistre og ægteskabs indgåelse ophørte med at have gyldighed i de sønderjyske landsdele.

Bekendtgørelsen af 2. jan. 1926 er opdelt i syv kapitler. Første kapitel indeholder de almindelige bestemmelser, nemlig at anmeldelse af fødsler, navngivelse og dødsfald med borgerlig gyldighed alene sker til personregisterførerne. De følgende bestemmelser om distrikter, personregisterførere og amtmandens tilsyn svarer til de da gældende bestemmelser. Kapitel 2 handler om anmeldelse af fødsler og navngivelser, hvor fristen for anmeldelse af navn fortsat er to måneder. Kapitel 3 handler om dødsfald og de følgende om anmeldelse af fødsler og dødsfald på rejser, berigtigelser af personregisteret, udskrifter og attester samt slutbestemmelser. Endelig medfølger tryk af blanketter. En nærmere redegørelse for enkeltheder kan ikke have interesse i denne sammenhæng, men det kan oplyses, at fængselsstraffen fra den tyske lovgivning er erstattet med bøder på 1-200 kr. Det er bemærkelsesværdigt, at det i §11 står, at enhver kan begære personregistrene forelagt til eftersyn på personregisterførerens kontor. Som et tillæg til bekendtgørelsen udsendtes 31. marts 1926 bestemmelser om angivelse af forsørgelseshjemsted $i$ registrene.

\section{Tiden efter 1931}

I 1931 udsendte professor O. A. Borum en oversigt over den i de sønderjyske landsdele endnu gældende særlovgivning, hvor der fyldigt redegøres for for- 
skellene indenfor personretten, herunder selve føringen af personregistre, hvor følgende enkeltheder er blandt de mere markante: Medens anmeldelse af en fødsel til kirkebogen i det øvrige Danmark skal ske inden to dage i byerne, 8 dage på landet, har man overalt i Sønderjylland 8 dages frist, navngivelse sker i øvrige land inden et år, i Sønderjylland inden to måneder, dødsfald anmeldes i resten af landet uopholdeligt til skifteretten, i Sønderjylland senest følgende søgnedag til personregisterføreren, der giver meddelelsen videre til skifteretten.

Således var status 10 år efter Genforeningen, og medens der siden da ikke er sket nogen ændring af selve grundforskellen, er der undervejs sket nogle justeringer. Således blev fristen for anmeldelse af fødsler og dødsfald i 1977 overalt fastsat til to dage, og ved navneloven i 1981 blev fristen for navngivning af et barn uanset om det skete til kirkebogsføreren eller personregisterføreren fastsat til 6 måneder.

I 1968 indførtes en borgerlig registrering i hele Danmark i form af CPRregisteret (Centralt Person Register) uden at dette fik umiddelbar konsekvens for førelsen af kirkebøger og personregistre, heller ikke selvom det udvalg, der blev nedsat 31.marts 1970 om borgerlig personregistrering, det såkaldte Henrik Nielsen-udvalg, i sin betænkning, der blev afgivet i 1972, klart kunne påvise endog meget betydningsfulde rationaliseringer og besparelser ved overgang til et videreudviklet CPR-system.

I stedet begyndte man at gennemføre en række administrative omlægninger, hvoraf følgende kan nævnes: Med nedlæggelsen af sognefogedembedet ved politikredsreformen 1973 overgik personregisterførelsen til en kommunal embedsmand. Med virkning fra 1.januar 1974 sammenlagdes de' gamle registreringsdistrikter som en konsekvens af kommunalreformen fra 1970, således at der herefter kun er eet registreringsdistrikt i hver kommune, som har til huse sammen med den kommunale forvaltning. Da Sønderjyllands amts grænser efter reformen 1970 ikke helt svarede til de tidligere amtsgrænser, blev personregisterførelsen bibeholdt i de sogne, der indlemmedes i Ribe kommune (Spandet, Hviding og Roager), medens den til gengald ikke blev indført i de sogne der indlemmedes i Christiansfeld kommune (Vejstrup, Taps og Hejls). At dette har givet anledning til megen usikkerhed, siger sig selv, når man betænker, at der gælder forskellige regler for samme kommunes borgere med hensyn til anmeldelser og udstedelse af attester. At det især har givet problemer i Ribe kommune og for Ribe amt som tilsynsmyndighed, kan ikke undre, da man ikke dér i forvejen kendte til personregistre.

Ved Justitsministeriets cirkulære af 1. dec. 1977 ændredes en række praktiske forhold ved personregistrene, idet der blev fastlagt normer for papirkvalitet, skriftstoffer m.v., som tillod, at man kunne udskrive personregistrene på løsblade $\mathrm{i}$ to eksemplarer $\mathrm{i}$ een arbejdsgang på skrivemaskine (et system, der 
Nye skemaer fra 1978. Fra 1.januar 1978 indfortes nye personregisterskemaer, som muliggjorde brug af skrivemaskine. Aret efter nedsatte Kirkeministeriet en arbejdsgruppe, der skulle undersoge muligheden for at benytte tilsvarende skemaer til kirkebogerne. Til brug for arbejdsgruppen havde personregisterforer Ruth Drabsch, Haderslev, udfyldt skemaer som dette, med fingerede navne. Forslaget vakte stor interesse, men blev aldrig gennemfort for kirkebogernes vedkommende.

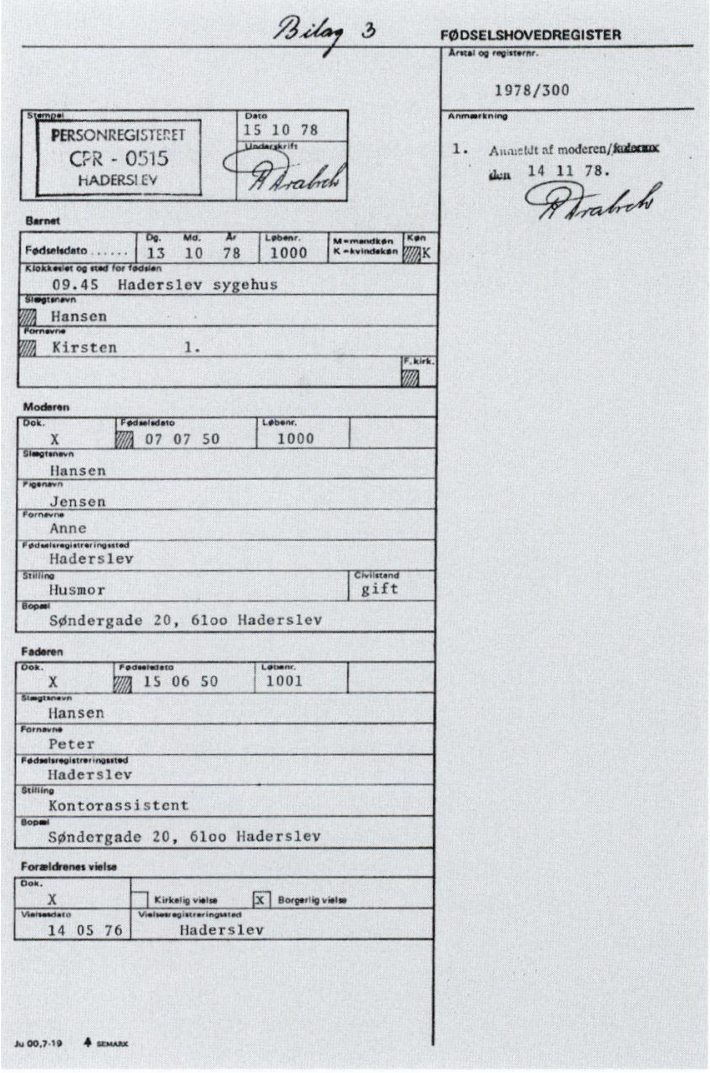

iøvrigt allerede siden 1.jan. 1970 havde været anvendt i de borgerlige vielsesregistre over hele landet). Samtidig ændredes reglerne for aflevering af personregistrene til landsarkivet, som hidtil havde modtaget biregistrene hvert år. De nye regler kom til at følge reglerne for aflevering af kirkebøgerne, såsåledes at biregistrene afleveres 30 år efter udskrivningen, hovedregistrene, når de er 100 år gamle.

Det var hensigten, at også kirkebogsførelsen skulle gennemgribende rationaliseres, og med dette for øje nedsatte Kirkeministeriet i 1979 en arbejdsgruppe, hvor undertegnede repræsenterede arkivvæsenet. Arbejdsgruppen aflagde undervejs besøg hos personregisterføreren i Haderslev for at se, hvorledes løsbladsystemet fungerede. Der var i udvalget stor tillid til, at et tilsvarende system kunne indføres for kirkebøgernes vedkommende, og i den rapport, som udvalget i 1985 afleverede til kirkeminister Mette Madsen, lå forslaget om de 

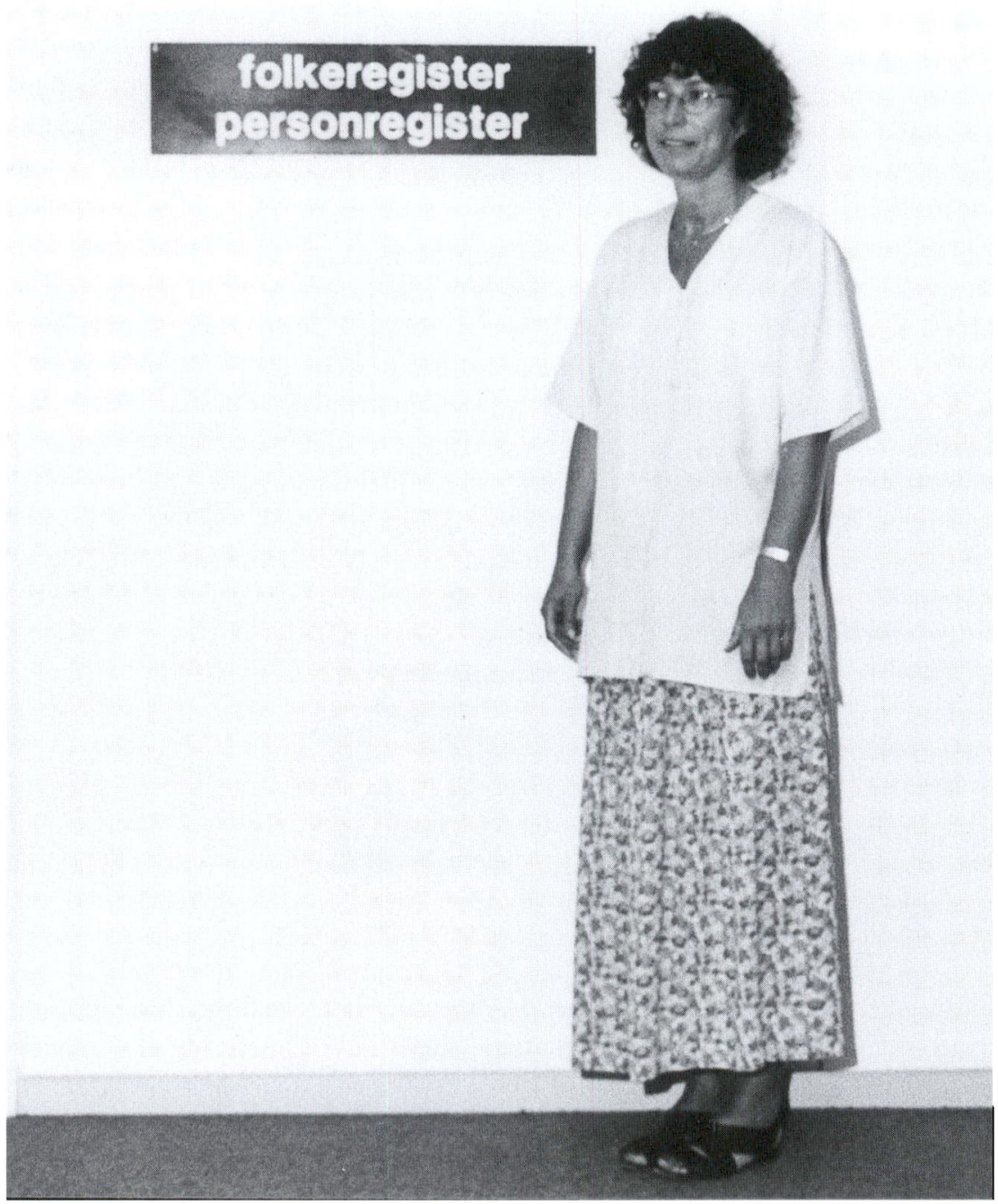

Kommunerne $i$ Sonderjylland rummer ikke blot folkeregistrene, som nord for Kongeåen. Også det sarlige personregister har til huse her, nasten ligesom for 1920. Dog er skiltningen knap sả imponerende som datidens orneskilte (s. 30I). Til gengald er der kommet kvindelige personregisterforere, her Else Tjornelund, Haderslev. Billedet er fra personregistret $i$ Haderslev. Foto: Per Christensen.

nye kirkebogsskemaer meget tæt op ad personregistrenes skemaer. Desværre var der ikke politisk mulighed for at gennemføre denne reform, og i stedet udarbejdede et mindre udvalg nye skemaer til håndskrevne kirkebøger, som 
blev indført ved Kirkeministeriets cirkulære af 14.aug. 1987 og efterfølgende cirkulæreskrivelse af 14. dec. 1987.

Forholdene idag er således ikke meget anderledes end i 1931. Nogle praktiske forhold er blevet ensrettet (anmeldefrister o.lg.), men grundlæggende er systemerne stadig forskellige, ja, man kan måske endog sige, at Sønderjylland yderligere har distanceret sig fra de traditionsbundne håndskrevne kirkebøger ved dog at indføre et mere moderne løsbladsystem og skrivemaskine. I vore nordiske broderlande er man i løbet af de seneste ti år gået over til borgerlig registrering, og selvom det næppe vil være populært at følge det svenske forbillede at lade skattevæsenet overtage personregistreringen, er der ikke tvivl om, at Henrik Nielsen-udvalgets konklusioner i dag har endnu mere vægt end for 23 år siden, således som informationsteknologien har udviklet sig. I et samfund, hvor forskellige trossamfund efterhånden har vundet indpas, er det også rimeligt med en neutral registreringsmyndighed. Endelig må det bemærkes, at set fra et kirkeligt synspunkt vil en tilbagevenden af kirkebøgerne til det, de oprindelig var, nemlig en registrering af den kristne menigheds kirkelige handlinger, ret beset være ønskelig, således som nogle præster også har tilsluttet sig det $\mathrm{i}$ den løbende debat.

Konklusionen må derfor blive, at det var rigtigt i 1920 at bibeholde den borgerlige personregistrering i Sønderjylland, og at det i 75-året for Genforeningen må være på tide omsider at få noget tilsvarende, dog i en moderniseret form, indført som fælles registreringsgrundlag i hele det nuværende Danmark.

\section{NOTER}

\section{Avisclebatten:}

Bismarck sparrer for Kim. Jydske-Vestkysten 8. juli 1993.

Venstres Pressetjeneste på Christiansborgs meddelelse af 25. okt.1994.

Fødselsattest eller dåbsattest. Jyllands Postens Midtpunkt ved Hans H. Worsøe 21. nov. 1994.

Hvem føres kirkebøgerne for? Kristeligt Dagblads kronik 1. dec. 1994 ved pastor Jens Kvist, Aabenraa.

Udnavnelsen af personregisterforeren $i$ Abild og de samtidige cirkularer:

Abild Personregisterførers arkiv: 1874-1963 Generalia og specialia. (Landsarkivet for Sønderjylland).

Forholdet sognefoged-personregisterforer og de interne cirkularer efter 1920:

Dybbøl personregisterførers arkiv: 1918-1950 Anordninger og cirkulærer.

Sønderborg amts journal nr. 15/163-1922 og 1367/27. (Landsarkivet for Sønderjylland).

\section{LITTERATURLISTE:}

De internationale forhold:

Paul Hinschius: Das Reichsgesetz über die Beurkundung des Personenstandes und die Eheschließung vom 6. Februar 1875. Zweite vermehrte Auflage. Berlin 1876. 
A. Erichsen: Die Führung der Standesregister. Praktische Anleitung für Standesbeamte. Achte vollständig neu bearbeitete Auflage. Berlin 1900.

J. G. J. van Booma: Genealogisch Onderzoek in Duitsland. s'Gravenhage, Centraal Bureau voor Genealogie, 1987

Pierre Durye: La Génealogie. Presses Universitaires de France. 5. ed. Paris 1979

De danske forhold:

Betonkning om borgerlig personregistrering afgivet af et udvalg nedsat den 31 .marts 1970 af Indenrigsministeriet. Betænkning nr. 649, 1972. (Henrik Nielsen-udvalget).

O. A. Borum: Oversigt over den i de sønderjyske Landsdele endnu gæeldende Særlovgivning, 1931.

Fra vision til handling: Info-samfundet år 2000 . Redegørelse til Folketinget om »Info-samfundet år $2000 \ll$ og IT-politisk handlingsplan 1995. Forskningsministeriet marts 1995.

A. Frees Christiansen: Registreringsdistrikterne i Sønderjylland 1874-1974, Præsteforeningens Blad nr. 7/1983 s. 101-104.

Frode Gribsvad og Johan Hvidtfeldt: Landsarkivet for de sønderjyske Landsdele. En Oversigt. Vejledende Arkivregistraturer VI, 1944. (s. 121 om personregisterførerarkiver).

P. G. Lindhardt: Tiden 1849-1901, Den danske Kirkes Historie, bd. VIII 1958.

Hans H. Worsøe: Slægtshistorie i Sønderjylland, 2. udg. 1984.

Paul G. Ørberg: Kirkebøger og kirkebogspolitik 1812-1920 i Kirkehistoriske Samlinger 1982 s. 12564.

De enkelte love og bekendtgorelser findes aftrykt $i$ :

Preussisch-deutscher Gesetz-Codex zusammengestellt von Paul Stoepel, Band IV. 1874-1878, Frankfurt a. O, 1881 .

Amtsblatt der königlichen Regierung zu Schleswig 1874 og 1875.

Kreisblatt fra de enkelte kredse.

Lovtidende og Ministerialtidende.

Rigsdagstidende (vedr. forarbejderne). 